\title{
Biodegradation of Keratin-Rich Husbandry Waste as a Path to Sustainable Agriculture
}

\author{
Anna Shestakova ${ }^{1}$, Svetlana Timorshina ${ }^{2, *(D)}$ and Alexander Osmolovskiy ${ }^{1,2, *(D)}$ \\ 1 Faculty of Biology and Biotechnology, HSE University, 101000 Moscow, Russia; aashestakova_4@edu.hse.ru \\ 2 Department of Microbiology, Faculty of Biology, Lomonosov Moscow State University, \\ 119991 Moscow, Russia \\ * Correspondence: timorshina.svetlana@mail.ru (S.T.); aosmol@mail.ru (A.O.)
}

check for

updates

Citation: Shestakova, A.; Timorshina, S.; Osmolovskiy, A. Biodegradation of Keratin-Rich Husbandry Waste as a Path to Sustainable Agriculture. Sustainability 2021, 13, 8691. https://doi.org/10.3390/su13168691

Academic Editors: Silvio Silvério da Silva, Peyman Abdeshahian, Felipe Antonio Fernandes Antunes and Avinash P. Ingle

Received: 30 June 2021

Accepted: 1 August 2021

Published: 4 August 2021

Publisher's Note: MDPI stays neutral with regard to jurisdictional claims in published maps and institutional affiliations.

Copyright: (C) 2021 by the authors. Licensee MDPI, Basel, Switzerland. This article is an open access article distributed under the terms and conditions of the Creative Commons Attribution (CC BY) license (https:/ / creativecommons.org/licenses/by/ $4.0 /)$.

\begin{abstract}
Every year, the size of the human population grows; with it, the need for agricultural products increases. This leads to an increment in the volume of waste, including hard-to-degrade keratin-rich ones, such as feathers. Currently, most of the agro-industrial complex protein by-products are utilized by incineration, landfilling, and chemical hydrolysis. Such methods do not meet modern trends in the development of a sustainable economy, negatively affecting the environment and humans, and preventing the reusing of waste. An alternative is biodegradation, which consists of the application of living organisms and their enzymes to recycle by-products. This approach is not only sustainable, but also makes it possible to obtain products of waste hydrolysis that are in demand for the manufacture of fertilizers and feed additives. This brings the development of agriculture closer to a circular economy and makes the recycling process more profitable. This review article emphasizes the significance of keratinolytic microorganisms and keratinases for the improvement of green methods for processing hard-to-degrade protein waste of the agro-industrial complex, which is necessary for sustainable economic development.
\end{abstract}

Keywords: keratinases; feather waste; enzyme technology; biodegradation; sustainability

\section{Introduction}

According to the human population projections of the United Nations, the global population will reach 10.1 billion people by 2060 [1]. Such rapid growth creates several serious difficulties for humanity, one of which is hunger. In 2020, 690 million people, or nine percent of the world, were subjected to undernutrition and the absence of decent foodstuffs and meals [2]. One sustainable development goal is to improve nutrition, achieve food security, and end hunger [3]. However, circumstances such as climate volatility, pest invasions, and lately, the COVID-19 pandemic, prevent the establishment of efficient food systems. One way to supply sufficient amounts of food is by increasing the sustainability of agriculture [4].

Animal husbandry not only provides animal products but also has an enormous environmental footprint [5]. However, it is not yet possible to abandon animal husbandry due to the amount of food that needs to be produced. Therefore, it is necessary to research and further use technologies that do not interfere with sustainable development.

Poultry products are the most available among livestock and the cheapest in manufacturing, and are therefore the most represented [6,7]. However, many solid wastes and by-products are also produced by bird farming, e.g., used bedding, feed residues, sawdust, hatchery and mortality waste, and other biological waste such as feces and feathers [8]. The latter can be especially difficult for disposal since it mostly contains the hard-to-degrade fibrillar keratin protein [9]. There are several methods of disposing of waste feathers, including incineration, landfilling, chemical hydrolysis, and carbonization [9-14]. Incineration, or burning, results in gas emissions, including greenhouse gases such as $\mathrm{CO}_{2}$ and $\mathrm{CO}$, as well as particulate matter and soot [12]. Landfilling keratin waste requires a burial 
area and may cause groundwater contamination, potentially leading to the infection of humans and animals [9]. Chemical hydrolysis is performed by harsh chemicals, either by acids or bases, followed by the recovery of substances used or disposal of undesirable salts $[10,11]$. Despite being in use, these approaches have significant disadvantages that do not meet current environmental trends and hinder sustainable development. Therefore, proper management of waste is required to optimize resource and energy consumption. It has also been shown that feathers can be carbonized to produce graphite materials and activated carbons that are in demand in various fields, including biocatalysis and bioremediation $[13,14]$. This method of waste disposal reduces the negative impact on the environment; however, it is energy intensive due to the need to apply a high temperature. Despite the obvious advantages of this approach, it also prevents the use of keratin-rich by-products as a source of amino acids and oligopeptides in agriculture, biomedicine, and pharmaceuticals.

Sustainability requires a set of approaches, one of which is the use of biotechnological methods in production and industry [15]. The use of biotechnology to dispose of poultry waste has been proposed already [16], but this approach seems to be the most relevant according to sustainability goals. Current investigations show a significant potential for the biotechnological treatment of waste, including keratin-rich waste [17]. The use of enzymes that break down keratin has several advantages over existing keratin-containing waste disposal methods. In contrast to the procedures mentioned above, enzymatic decomposition does not emit gases into the atmosphere, and there is no risk of contamination; enzyme treatment also allows the minimization of wastewaters and does not require land areas. In addition, enzymatically processed raw materials can be used for other industries such as fertilizers and feed additives $[18,19]$, which is significant for sustainable farming and agriculture. The enzymes that perform the hydrolysis of keratin, or keratinases, may be produced by different organisms, mainly bacteria and filamentous fungi. These microorganisms can grow on various substrates, including wastes, while secreting extracellular enzymes with different substrate specificity and performance optima [20-22]. These characteristics make it possible to consider bacteria and micromycetes as promising producers of keratinases for sustainable agriculture. Using green catalysts for waste management is essential to meet current human needs while conserving the environment and resources.

This mini-review aims to summarize current data on the state of the poultry sector to emphasize the need to develop new sustainable keratin-rich waste disposal methods, as well as to discuss existing biotechnological approaches to solve this problem. To achieve this goal, information was collected and analyzed from open databases such as the Food and Agriculture Organization of the United Nations and topical articles of current interest.

\section{Poultry Industry Dynamics and Analysis}

Although pork is the most consumed type of meat worldwide, the poultry industry is growing most significantly [6]. The term "poultry" includes a wide range of domestic and indigenous birds, such as chickens, ducks, turkeys, guinea fowl, geese, etc. [23]. According to the Food and Agriculture Organization of the United Nations, in 2019, the poultry population reached almost 77 billion heads, of which chickens represented the majority, reaching $94 \%$, followed by ducks $(4 \%)$, and geese and guinea fowl $(1 \%)$. The total amount of primary livestock poultry production in 2019 was estimated at 131,647,239 tons [24].

The coronavirus pandemic has disrupted supply chains due to production shutdowns and closed borders, but a compound annual growth rate (CAGR) of $3.8 \%$ is expected in 2021, provided by production recovery [25]. Moreover, according to The Business Research Company's report, annual chicken meat sales will reach $\$ 71.08$ billion in 2023 [7].

In addition to the target compounds, poultry production generates by-products such as offal, heads, legs, beaks, skin, cartilage, bones, blood, and feathers [26]. The content of poultry by-products and their estimated amount of protein is presented in Table 1 . These residues may be disposed of or somehow processed and applied in different fields. There are the following ways to meet sustainable development trends in waste management: 
poultry by-products may be converted to edible material directly or indirectly via plant fertilizers manufacturing or processed into value-added products. The latter are feed additives, fertilizers, meals, biodegradable materials, biofuel, etc. $[27,28]$. For sustainable development, it is necessary to minimize the impact of waste on the environment, that is, to find a use for the resulting debris. Feathers are tough to utilize and process, although they have great applicable potential since they have a high protein content and make up a significant percentage of the bird's body weight.

Table 1. Types of poultry by-products and their protein content.

\begin{tabular}{cccc}
\hline By-Product & $\begin{array}{c}\text { Percentage of Body Mass } \\
\text { per Component, } \%\end{array}$ & Protein Content, $\%$ & References \\
\hline Blood & $6-7.5$ & $28-31$ & {$[29,30]$} \\
Bones and cartilage & $22-24$ & $20-24$ & {$[31,32]$} \\
Feathers & $7-9$ & up to 90 & {$[33]$} \\
Offal & 6 & 32 & {$[8,34]$} \\
\hline
\end{tabular}

\section{Chicken Feather Waste and Current Waste Management}

Even though keratin-containing by-products are formed during poultry farming, pig farming, and cattle farming, chicken feathers constitute the most abundant type of keratin residues [35]. Therefore, proper management of produced feathers is necessary and relevant. Although a minor part of the feathers is proceeded to feather meal and fertilizers, it is considered waste. Assuming that the mass of feather cover is up to $9 \%$ of the bird's weight [24], the amount of feather waste can be estimated at 11,848,251 tons worldwide, according to data provided by the Food and Agriculture Organization of the United Nations for 2019.

Contaminated poultry by-products, particularly feathers, contain different species of microorganisms, including Salmonella sp., Staphylococcus sp., and Clostridium sp. [36], which are harmful pathogens. In addition, veterinary drugs, antibiotics, and other chemical compounds applied in poultry farming may also cause water and soil pollution [37]. Therefore, incorrect disposal of feathers can lead to environmental damage, water contamination, and the spread of diseases.

Their structure provides the complexity of the destruction of such wastes. The main compound of feathers is keratin-a hard-to-degrade fibrous structural protein found in vertebrates. There are three distinguished types of keratin: $\alpha$-keratins, which are usually found together with $\gamma$-keratins; and $\beta$-keratins [38]. $\alpha$-keratins are present in all vertebrates and their secondary structure is dominated by alpha helices immersed in a matrix consisting of gamma keratin, for which the predominance of one of the secondary structures has not been described. $\beta$-keratins occur in reptiles and birds; their polypeptide chains form beta sheets [27]. Despite structural differences, it was found that keratins evolved simultaneously and are encoded by a gene family common to mammals, birds, and reptiles. Keratins are distinguished from many other biopolymers by a higher percentage of cysteine, and as a result, its dimerized form, cystine, provides keratin with increased resistance to hydrolysis [39]. Although cystine content is higher in alpha keratin, beta keratin molecules are stabilized by non-covalent interactions between beta sheets, so its structure complicates the hydrolysis and processing of feathers [40]. There are several ways to treat feathers. Table 2 describes some characteristics of these methods and explains the advantages and disadvantages of each. 
Table 2. Feather waste disposal methods.

\begin{tabular}{|c|c|c|c|}
\hline Method of Treatment & Advantages & Disadvantages & References \\
\hline Incineration & $\begin{array}{c}\text { Ash produced is safe and decontaminated } \\
\text { Ash may be used as a fertilizer } \\
\text { Allows the disposal of large volumes of } \\
\text { waste }\end{array}$ & $\begin{array}{c}\text { Air pollution } \\
\text { Causes bad smell, fumes, and smog } \\
\text { Special equipment required }\end{array}$ & {$[12,41-43]$} \\
\hline Burial & $\begin{array}{l}\text { Avoids unpleasant odors } \\
\text { A relatively economical option }\end{array}$ & $\begin{array}{l}\text { Groundwater contamination risk } \\
\text { Soil and water pollution risk } \\
\text { Landfill area required } \\
\text { Burial is difficult when the ground is } \\
\text { wet or frozen }\end{array}$ & {$[9,37,44,45]$} \\
\hline Chemical hydrolysis & $\begin{array}{l}\text { Results in the production of low molecular } \\
\text { weight components }\end{array}$ & $\begin{array}{l}\text { Requires dangerous, harsh chemicals } \\
\text { Requires disposal or recycling of } \\
\text { residues and undesirable salts needed } \\
\text { Large amounts of wastewater produced }\end{array}$ & {$[10,11]$} \\
\hline Biodegradation & $\begin{array}{l}\text { Allows the obtainment of hydrolysate } \\
\text { containing single compounds such as } \\
\text { oligopeptides and amino acids } \\
\text { A relatively energy-efficient process } \\
\text { No emissions and environmental pollution } \\
\text { Safe for people and animals }\end{array}$ & Potentially difficult to scale up & {$[18,46]$} \\
\hline
\end{tabular}

Incineration is the most common method of feather disposal [47], but it does not allow the reuse of waste to receive additional benefits and results in greenhouse gas emissions, which lead to global warming and must be avoided in the future. Thus, the existing methods, except for biodegradation, have significant drawbacks that do not satisfy sustainable conservation management. Continued use of these approaches can lead to the depletion of resources and damage to ecosystems. As an alternative green approach, biodegradation can replace unsustainable practices, but it requires additional research, optimization, and technological development.

\section{Biodegradation of Keratin Waste}

Biodegradation of keratin waste is primarily the destruction of keratin by enzymes of microorganisms. Enzymes that can break down keratin are known and are called keratinases (EC 3.4.21/24/99). They are synthesized by various producers, mainly bacteria and fungi [48].

The ability to synthesize keratinolytic enzymes has long been associated with dermatophyte organisms, whose pathogenicity did not allow the biotechnological optimization of enzyme production [49]. However, further works showed that the formation of keratinases is not an exclusive property for pathogenic organisms [50,51], which made it possible to form a biotechnology research area aimed at studying and using keratinases that are in demand in many sectors of the economy, and at the same time do not pose a danger to humans.

Some keratinase-containing commercially used products are known. They are applied in biomedicine, pharmaceuticals, cosmetology, biodecontamination, and animal feed preparation (Table 3). However, these products have limitations in their use because of their prices, provided by the production, obtainment, and multi-stage purification of them. For biodegradation, scaling up keratinase production is essential since large volumes of feather waste are produced. Therefore, enzyme production costs should be kept to a minimum. The introductory price of keratinases, which does not include isolation and purification, is lower than other enzymes since feathers, which are waste, can be used as a food substrate to synthesize keratinases. The use of difficult-to-hydrolyze poultry waste as a nutrition substrate for the cultivation of microorganisms and the production of their 
enzymes is a green and sustainable approach to the production of keratinases for their further application [52].

Table 3. Keratinase-containing commercially used products.

\begin{tabular}{|c|c|c|c|}
\hline Product Name & Source & Area of Application & Manufacturer \\
\hline FEED-0001 & \multirow{10}{*}{ Bacillus licheniformis } & $\begin{array}{l}\text { Production of feed additives } \\
\text { for animals }\end{array}$ & Creative Enzymes \\
\hline Valkerase & & $\begin{array}{l}\text { Production of feed additives } \\
\text { for animals }\end{array}$ & $\begin{array}{l}\text { BioResource International, } \\
\text { Inc. }\end{array}$ \\
\hline Versazyme & & $\begin{array}{l}\text { Production of feed additives } \\
\text { for animals }\end{array}$ & $\begin{array}{l}\text { BioResource International, } \\
\text { Inc. }\end{array}$ \\
\hline Prionzyme TM & & Prion degradation & Genencor International, Inc. \\
\hline Keratoclean PB & & Cosmetology & Proteos Biotech \\
\hline Keratoclean HYDRA PB & & Cosmetology & Proteos Biotech \\
\hline Keratoclean sensitive PB & & Cosmetology & Proteos Biotech \\
\hline Keratopeel PB & & Cosmetology & Proteos Biotech \\
\hline PURE100 KERATINASE & & $\begin{array}{l}\text { Cosmetology, prion } \\
\text { degradation }\end{array}$ & Proteos Biotech \\
\hline Alcalase (protease P4860) & & Scientific research & Novozymes Crop. \\
\hline Esperase (protease P5860) & \multirow{2}{*}{ Bacillus sp. } & Scientific research & Novozymes Crop. \\
\hline Savinase (protease P3111) & & Scientific research & Novozymes Crop. \\
\hline NATE-0853 & $\begin{array}{l}\text { recombinant strain Escherichia } \\
\text { coli BL21 }\end{array}$ & Scientific research & Creative Enzymes \\
\hline Proteinase $\mathrm{k}$ & $\begin{array}{l}\text { Engyodontium album (earlier } \\
\text { Tritirachium album) and } \\
\text { recombinant strains }\end{array}$ & Scientific research & Various \\
\hline FixaFungus & - & Treatments of toe nail & FixaFungus \\
\hline Bioguard Plus & $\begin{array}{l}\text { Proprietary blend of multiple } \\
\text { microorganisms cultures } \\
\text { including keratinolytic }\end{array}$ & Cleaning agents & RuShay, Inc. \\
\hline
\end{tabular}

From the data presented in Table 3, it can be seen that Bacillus licheniformis is the most common producer of keratinases in the industry. However, a large number of articles by researchers from different countries are published annually on the search and study of previously unknown producers of keratinolytic enzymes, as well as on the development of new approaches to increase the synthesis of target proteases [53-62].

The use of keratinolytic enzymes to destroy keratin waste is a promising method for obtaining fertilizers and feed additives for livestock due to the high protein content in feathers [33,63]. In addition, the substances obtained during hydrolysis can be used as a substrate for the cultivation of microorganisms, in particular, for the production of bioelectricity and biofuel [64-66], which has a positive effect on reducing the environmental footprint left by agriculture and also allows the reduction in energy costs within individual enterprises. Scaled-up production of low molecular weight compounds by biodegradation of keratin waste may create a closed-loop supply chain at poultry farms and agricultural complexes, significantly reducing farming's ecological trail. An independent transition from final disposal to feedstocks is an essential step toward sustainability. In addition, such resource use will reduce the cost of purchasing premixes, amino acids, and fertilizers, which is economically favorable. Figure 1 illustrates a potential strategy of the application of keratin biodegradation in terms of sustainable agriculture. 


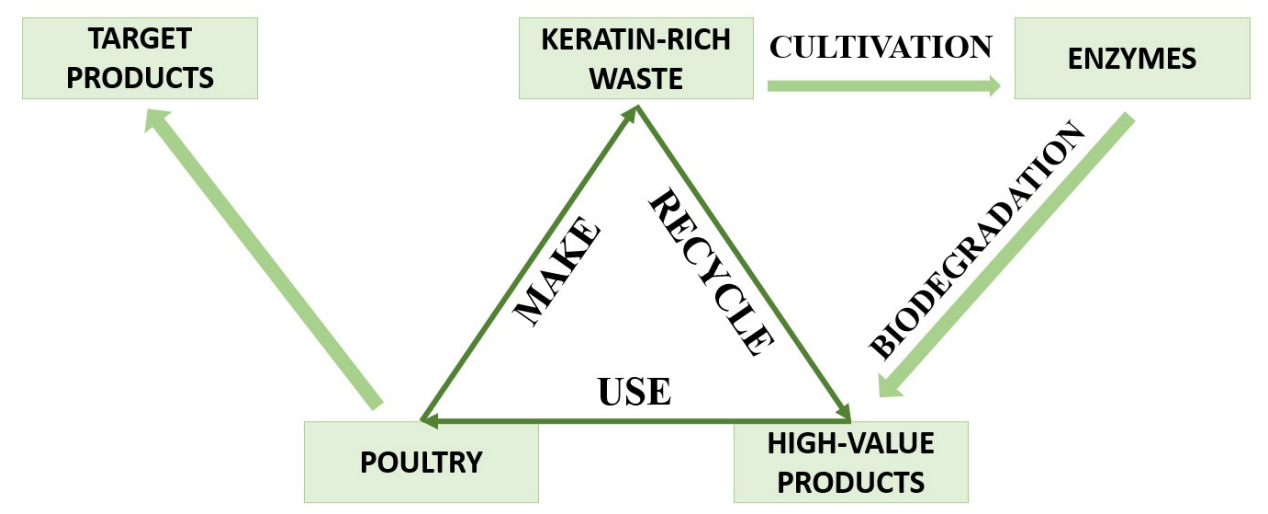

Figure 1. Biodegradation of keratin-containing waste in the poultry production cycle.

Hence, biodegradation is a robust approach to keratin-rich waste disposal. As it was previously illustrated, using green catalysts reduces the negative impact on the environment. Unlike existing feather-treatment methods, applying microorganisms and enzymes is affordable and does not lead to resource depletion. It also does not pollute the atmosphere and allows one to obtain many substances that can be further used in manufacturing. Therefore, this approach is vital in the transition to a circular economy that is necessary for sustainable development.

\section{Keratinases, Their Sources and Use for Biodegradation}

Keratinolytic microorganisms are found in all three domains (Bacteria, Archaea, and Eukarya); however, bacteria and micromycetes capable of secreting keratinases are of the greatest interest to the industry. Each of these sources of target enzymes has its own advantages and disadvantages.

Among non-pathogenic and conditionally pathogenic bacteria, representatives of many taxonomic groups exhibit the ability to secrete keratinolytic enzymes, but this property is most common among organisms of the genus Bacillus, for example, Bacillus licheniormis and Bacillus subtilis. In addition, filamentous bacteria, such as Streptomyces sp. and Actinomadura sp., are capable of the hydrolysis of keratin-rich substrates. Nowadays, only fungi-synthesized keratinases are known in the domain Eukarya. From time to time, reports have been published about this ability in some insects, but it was later shown that the assimilation of keratin is associated with the presence of keratinolytic microorganisms in the intestinal microbiota. Currently, the most studied ability to produce keratinolytic enzymes is in non-pathogenic and conditionally pathogenic fungi, among micromycetes of the genera Aspergillus, Doratomyces, Myrothecium, Penicillium, Purpureocillium, Scopulariopsis, Trichoderma and also ascomycete yeast Candida and the basidiomycete genus Coriolopsis [21,22].

Keratinases can be intracellular, membrane-bound, and extracellular enzymes [67-71]. However, microorganisms more often release them into the external environment, which is biotechnologically beneficial since it increases the availability of the enzymes for isolation and purification and, therefore, reduces the cost of the process. Even though organisms with the constitutive synthesis of keratinases are known [72], most keratinolytics form target enzymes inducibly when growing on keratin-containing substrates acting as a carbon and nitrogen source [21,73]. The cultivation parameters of keratinolytic microorganisms vary and depend on the biology of the producer. For most keratinolytics, the optimal level of acidity of the medium, at which degradation of the keratin-containing substrate is observed, lies in the range of $\mathrm{pH}$ 6-9. An alkaline $\mathrm{pH}$ can increase the availability of keratin for enzymes since, at high $\mathrm{pH}$ values, lanthionine is formed from cysteine, which is more accessible for hydrolysis. In addition, under the conditions of submerged fermentation, many producers may experience an increase in the $\mathrm{pH}$ of the culture liquid caused by deamination reactions occurring during protein degradation [17]. The optimum temperature for keratinase synthesis varies from 28 to $50{ }^{\circ} \mathrm{C}$ for most bacteria and 
fungi, except for some thermophilic and psychrophilic organisms [17]. The synthesis of keratinases is shown in submerged fermentation both under stirring and static conditions. In addition, the synthesis of keratinolytic enzymes can also occur during solid-state fermentation [51,74-77].

Solid-state fermentation requires little water consumption and, accordingly, creates little wastewater and does not demand the use of antifoams, which is an advantage of this method for preserving the environment. Hence, growing keratinolytic microorganisms in such conditions meets the trends of sustainable development. Furthermore, no harsh substances are used during biodegradation, as in chemical hydrolysis. Moreover, fermentation can also occur in a confined space, an advantage over burial, requiring particular areas for landfilling. In addition, as a result of enzymatic hydrolysis, low-molecular-weight proteins, oligopeptides, and amino acids are formed [9]. This makes it possible to use the waste from the agro-industrial complex, implementing the full potential of the biomaterial, which reduces the load on the environment and allows the partial closure of the life cycle of the by-products [78]. It is worth noting that hyphae of micromycete growing in such conditions can braid and penetrate the structures they destroy, facilitating and accelerating the decomposition process of the keratin-containing material [49]. For example, the growth of Trichoderma harzianum on feather meal, when is used as a substrate for solid-state fermentation, increases the production of keratinases by seven times compared to that of submerged cultivation, which is widespread in industry [79]. The efficiency of using feather meal for the synthesis of keratinolytic enzymes under solid-state conditions was also shown for the culture of Aspergillus niger [80].

For some keratin-degrading enzymes, broad substrate specificity is known. It has been shown that some keratinases have the ability to break down substrates such as casein, gelatin, bovine serum albumin, hemoglobin, silk fibroin, collagen, and elastin. Hence, their activity is not limited exclusively to the hydrolysis of keratin [21,73]. In addition, fungal enzymes may have a more diverse structure since the structure of the eukaryotic cell of the producer fungus allows the synthesis of proteins to be modified, for example, by glycosylation, which potentially increases the diversity, resistance, and range of conditions in which these protein catalysts can function [81].

Despite the vast possibilities of modern bioengineering and the relative simplicity of manipulating the genomes of prokaryotes [82-85], exploratory research to study new sources of keratinases remains relevant and in high demand due to the low level of accumulated knowledge and high prospects of keratinolytic micromycetes [80,86,87].

\section{Conclusions}

Industrialization and technological development have significantly impacted living standards and changed many of the usual production processes. The growth of the world's population has resulted in the problem of hunger, a solution of which leads to the depletion of natural resources and climate change. Production rates of animal products have grown tremendously, along with the amount of waste. Poultry farming leads to the formation of a large quantity of hardly hydrolyzable keratin-containing feather waste, mainly disposed of by incineration, burial, or chemical hydrolysis. These approaches exacerbate environmental problems and also hinder the rational use of resources and conservation. A green alternative in a sustainable environment is the use of green catalysts. Various microorganisms can synthesize enzymes capable of degrading rigid keratin, but fungal keratinases have vast biotechnological potential. While growing on feather waste, fungi can secrete target enzymes with various properties, substrate specificity, and working conditions. Enzymatic hydrolysis allows rational waste disposal and results in obtaining different biobased products, which can then be returned into the production cycle. Research and the further application of biodegradation of keratin-containing poultry waste is an essential and significant step towards sustainability.

Author Contributions: Writing, A.S.; supervision and editing, S.T.; project administration and editing, A.O. All authors have read and agreed to the published version of the manuscript. 
Funding: This research was funded by the Foundation for Assistance to Small Innovative Enterprises "UMNIK" program, grants number 16404ГУ / 2021 and 17034ГУ / 2021.

Institutional Review Board Statement: Not applicable.

Informed Consent Statement: Not applicable.

Data Availability Statement: Not applicable.

Conflicts of Interest: The authors declare no conflict of interest.

\section{References}

1. United Nations. Available online: https://population.un.org/wpp/Download/Probabilistic/Population/ (accessed on 29 June 2021).

2. Food and Agriculture Organization of the United Nations. Available online: http://www.fao.org/documents/card/en/c/ca969 9en (accessed on 29 June 2021).

3. Gulseven, O.; Al Harmoodi, F.; Al Falasi, M.; ALshomali, I. How the COVID-19 Pandemic Will Affect the UN Sustainable Development Goals? SSRN Electron. J. 2020. Available online: https://papers.ssrn.com/sol3/papers.cfm?abstract_id=3592933 (accessed on 29 June 2021). [CrossRef]

4. Sustainable Agriculture Research \& Education Program. Available online: https://sarep.ucdavis.edu/sustainable-ag (accessed on 29 June 2021).

5. Brown, L. The Emerging Politics of Food Scarcity. In World on the Edge, 1st ed.; W. W. Norton \& Company: New York, NY, USA, 2011; pp. 59-71.

6. Ritchie, H.; Roser, M. Meat and Dairy Production. 2019. Available online: https:/ / ourworldindata.org/meat-production\#citation (accessed on 29 June 2021).

7. The Business Research Company. Available online: https://www.thebusinessresearchcompany.com/report/poultry-market (accessed on 29 June 2021).

8. Singh, P.; Mondal, T.; Sharma, R.; Mahalakshmi, N.; Gupta, M. Poultry Waste Management. Int. J. Curr. Microbiol. App. Sci. 2018, 7, 694-700. [CrossRef]

9. Tesfaye, T.; Sithole, B.; Ramjugernath, D. Valorisation of chicken feathers: A review on recycling and recovery route-Current status and future prospects. Clean Technol. Environ. Policy 2017, 19, 2363-2378. [CrossRef]

10. Bouhamed, S.; Kechaou, N. Kinetic study of sulphuric acid hydrolysis of protein feathers. Bioprocess Biosyst. Eng. 2017, 40, 715-721. [CrossRef]

11. Pahua-Ramos, M.; Hernandez-Melchor, D.; Camacho-Pérez, B.; Quezada-Cruz, M. Degradation of chicken feathers: A review. Biotechnol. Ind. J. 2017, 13, 1-24.

12. Stingone, J.; Wing, S. Poultry litter incineration as a source of energy reviewing the potential impacts on environmental health and justice. New Solut. 2011, 21, 27-42. [CrossRef] [PubMed]

13. Chiramba, R.; Charis, G.; Fungura, N.; Danha, G.; Mamvura, T. Production of activated carbon from poultry feathers for waste water treatment. Water Sci. Technol. 2019, 80, 1407-1412. [CrossRef] [PubMed]

14. Pajarito, B.; Belarmino, A.; Calimbas, R.; Gonzales, J. Graphite Nanoplatelets from Waste Chicken Feathers. Materials 2020, 13, 2109. [CrossRef]

15. Williams, K.; Page, M. Biotechnology and Sustainability: A Symbiotic Relationship. Bus. Res. Yearb. 2011, 18, 548-555.

16. Onifade, A.; Al-Sane, N.; Al-Musallam, A.; Al-Zarban, S. A review: Potentials for biotechnological applications of keratindegrading microorganisms and their enzymes for nutritional improvement of feathers and other keratins as livestock feed resources. Bioresour. Technol. 1998, 66, 1-11. [CrossRef]

17. Nnolim, N.; Udenigwe, C.; Okoh, A.; Nwodo, U. Microbial Keratinase: Next Generation Green Catalyst and Prospective Applications. Front. Microbiol. 2020, 11, 3280. [CrossRef]

18. Tamreihao, K.; Mukherjee, S.; Khunjamayum, R.; Devi, L.; Asem, R.; Ningthoujam, D. Feather degradation by keratinolytic bacteria and biofertilizing potential for sustainable agricultural production. J. Basic Microbiol. 2019, 59, 4-13. [CrossRef] [PubMed]

19. de Menezes, C.; Santos, R.; Santos, M.; Boscolo, M.; da Silva, R.; Gomes, E.; da Silva, R.R. Industrial sustainability of microbial keratinases: Production and potential applications. World J. Microbiol. Biotechnol. 2021, 37, 86. [CrossRef]

20. Gupta, V.; Kubicek, C.; Berrin, J.-G.; Wilson, D.; Couturier, M.; Berlin, A.; Filho, E.; Ezeji, T. Fungal Enzymes for Bio-Products from Sustainable and Waste Biomass. Trends Biochem. Sci. 2016, 41, 633-645. [CrossRef]

21. Hassan, M.; Abol-Fotouh, D.; Omer, A.; Tamer, T.; Abbas, E. Comprehensive insights into microbial keratinases and their implication in various biotechnological and industrial sectors: A review. Int. J. Biol. Macromol. 2020, 154, 567-583. [CrossRef]

22. Qiu, J.; Wilkens, C.; Barrett, K.; Meyer, A. Microbial enzymes catalyzing keratin degradation: Classification, structure, function. Biotechnol. Adv. 2020, 44, 107607. [CrossRef] [PubMed]

23. Food and Agriculture Organization of the United Nations. Available online: http://www.fao.org/poultry-production-products/ production/poultry-species / other-poultry / en / (accessed on 29 June 2021).

24. Food and Agriculture Organization of the United Nations. Available online: http://www.fao.org/faostat/en/\#data/QL (accessed on 29 June 2021). 
25. Poultry Global Market Report 2021: COVID-19 Impact and Recovery to 2030. Available online: https:/ / www.researchandmarkets. com/reports /5240275/poultry-global-market-report-2021-covid-19?utm_source=CI\&utm_medium=PressRelease\&utm_ code=cbjc99\&utm_campaign=1502793+-+Global+Poultry+Market+Report+2021\&utm_exec=chdo54prd (accessed on 29 June 2021).

26. Lasekan, A.; Abu Bakar, F.; Hashim, D. Potential of chicken by-products as sources of useful biological resources. Waste Manag. 2013, 33, 552-565. [CrossRef] [PubMed]

27. Sharma, S.; Gupta, A. Sustainable management of keratin waste biomass: Applications and future perspectives. Braz. Arch. Biol. Technol. 2016, 59, e16150684. [CrossRef]

28. Seidavi, A.; Zaker-Esteghamati, H.; Scanes, C. Poultry Byproducts. In Byproducts from Agriculture and Fisheries; Simpson, B., Aryee, A., Toldrá, F., Eds.; John Wiley \& Sons Ltd.: Hoboken, NJ, USA, 2019; pp. 123-146.

29. Kelly, L.; Alworth, L. Techniques for collecting blood from the domestic chicken. Lab. Anim. 2013, 42, 359-361. [CrossRef]

30. Fleischer, L.-G.; Gerber, G.; Liezenga, R.; Lippert, E.; Scholl, M.; Westphal, G. Blood cells and plasma proteins of chickens fed a diet supplemented with (1->3),(1->6)- 3 -D-Glucan and enrofloxacin. Arch. Anim. Nutr. 2000, 53, 59-73. [CrossRef]

31. Hayse, P.; Marion, W. Eviscerated Yield, Component Parts, and Meat, Skin and Bone Ratios in the Chicken Broiler. Poult. Sci. 1973, 52, 718-722. [CrossRef]

32. Suchý, P.; Straková, E.; Herzig, I.; Steinhauser, L.; Kralik, G.; Zapletal, D. Chemical composition of bone tissue in broiler Chickens intended for slaughter. Czech J. Anim. Sci. 2009, 54, 324-330. [CrossRef]

33. Grazziotin, A.; Pimentel, F.; Jong, E.; Brandelli, A. Poultry feather hydrolysate as a protein source for growing rats. Braz. J. Vet. Res. Anim. Sci. 2008, 45, 61-67. [CrossRef]

34. Abdullah, F.; Buchtová, H. Comparison of qualitative and quantitative properties of the wings, necks and offal of chicken broilers from organic and conventional production systems. Veterinární Med. 2016, 61, 643-651. [CrossRef]

35. Fagbemi, O.D.; Sithole, B.; Tesfaye, T. Optimization of keratin protein extraction from waste chicken feathers using hybrid pre-treatment techniques. Sustain. Chem. Pharm. 2020, 17, 100267. [CrossRef]

36. Thyagarajan, D.; Barathi, M.; Sakthivadivu, R. Scope of Poultry Waste Utilization. J. Agric. Vet. Sci. 2013, 6, 29-35.

37. Cornejo, J.; Pokrant, E.; Carvallo, C.; Maddaleno, A.; San Martín, B. Depletion of tylosin residues in feathers, muscle and liver from broiler chickens after completion of antimicrobial therapy. Food Addit. Contam. Part A 2018, 35, 448-457. [CrossRef]

38. Kadir, M.; Wang, X.; Zhu, B.; Liu, J.; Harland, D.; Popescu, C. The structure of the "amorphous" matrix of keratins. J. Struct. Biol. 2017, 198, 116-123. [CrossRef]

39. Strasser, B.; Mlitz, V.; Hermann, M.; Tschachler, E.; Eckhart, L. Convergent evolution of cysteine-rich proteins in feathers and hair. BMC Evol. Biol. 2015, 15, 82. [CrossRef]

40. Alibardi, L. Cornification in reptilian epidermis occurs through the deposition of keratin-associated beta-proteins (beta-keratins) onto a scaffold of intermediate filament keratins. J. Morphol. 2013, 274, 175-193. [CrossRef]

41. Sakudo, A. Inactivation Methods for Prions. Curr. Issues Mol. Biol. 2020, 36, 23-32. [CrossRef]

42. Staroń, P.; Kowalski, Z.; Staroń, A.; Banach, M. Thermal treatment of waste from the meat industry in high scale rotary kiln. Int. J. Environ. Sci. Technol. 2017, 14, 1157-1168. [CrossRef]

43. Marculescu, C.; Stan, C. Poultry processing industry waste to energy conversion. Energy Procedia 2011, 6, 550-557. [CrossRef]

44. Glanville, T.; Ahn, H.; Richard, T.; Shiers, L.; Harmon, J. Soil Contamination Caused by Emergency Bio-Reduction of Catastrophic Livestock Mortalities. Water Air Soil Pollut. 2009, 198, 285-295. [CrossRef]

45. Carcass Disposal: A Comprehensive Review. Available online: https://amarillo.tamu.edu/files/2011/01/draftreport.pdf (accessed on 29 June 2021).

46. Ghaffar, I.; Imtiaz, A.; Hussain, A.; Javid, A.; Jabeen, F.; Akmal, M.; Qazi, J. Microbial production and industrial applications of keratinases: An overview. Int. Microbiol. 2018, 21, 163-174. [CrossRef]

47. Kodak, S.; Gharge, T.; Chavan, V.; Sibi, G. Microbial Degradation of Poultry Feather Wastes under the Influence of Temperature and Ph-A Review. Int. J. Environ. Sci. Nat. Res. 2019, 21, 556063.

48. Lange, L.; Huang, Y.; Busk, P.K. Microbial decomposition of keratin in nature-A new hypothesis of industrial relevance. Appl. Microbiol. Biotechnol. 2016, 100, 2083-2096. [CrossRef]

49. Watts, C.; Wagner, D.; Sohnle, P. Fungal infections, cutaneous. In Encyclopedia of Microbiology, 2nd ed.; Academic: San Diego, CA, USA, 2000; pp. 382-388.

50. Gupta, R.; Ramnani, P. Microbial keratinases and their prospective applications: An overview. Appl. Microbiol. Biotechnol. 2006, 70, 21-33. [CrossRef]

51. Mazotto, A.; Courib, S.; Damasod, M.; Vermelho, A. Degradation of feather waste by Aspergillus niger keratinases: Comparison of submerged and solid-state fermentation. Int. Biodeterior. Biodegrad. 2013, 85, 189-195. [CrossRef]

52. Casarin, F.; Cladera-Olivera, F.; Brandelli, A. Use of Poultry Byproduct for Production of Keratinolytic Enzymes. Food Bioprocess. Technol. 2008, 1, 301-305. [CrossRef]

53. Kang, E.; Jin, H.; La, J.; Sung, J.; Park, S.; Kim, W.; Lee, D. Identification of keratinases from Fervidobacterium islandicum AW-1 using dynamic gene expression profiling. Microb. Biotechnol. 2020, 13, 442-457. [CrossRef]

54. Duffeck, C.; de Menezes, C.; Boscolo, M.; da Silva, R.; Gomes, E.; da Silva, R.R. Keratinases from Coriolopsis byrsina as an alternative for feather degradation: Applications for cloth cleaning based on commercial detergent compatibility and for the production of collagen hydrolysate. Biotechnol. Lett. 2020, 42, 2403-2412. [CrossRef] 
55. González, V.; Vargas-Straube, M.; Beys-da-Silva, W.; Santi, L.; Valencia, P.; Beltrametti, F.; Cámara, B. Enzyme Bioprospection of Marine-Derived Actinobacteria from the Chilean Coast and New Insight in the Mechanism of Keratin Degradation in Streptomyces sp. G11C. Mar. Drugs 2020, 18, 537. [CrossRef]

56. Nnolim, N.; Okoh, A.; Nwodo, U. Proteolytic bacteria isolated from agro-waste dumpsites produced keratinolytic enzymes. Biotechnol. Rep. 2020, 27, e00483. [CrossRef]

57. Li, Z.; Liang, S.; Ke, Y.; Deng, J.; Zhang, M.; Lu, D.; Li, J.; Luo, X. The feather degradation mechanisms of a new Streptomyces sp. isolate SCUT-3. Commun. Biol. 2020, 3, 191. [CrossRef]

58. Nnolim, N.; Ntozonke, N.; Okoh, A.; Nwodo, U. Exoproduction and characterization of a detergent-stable alkaline keratinase from Arthrobacter sp. KFS-1. Biochimie 2020, 177, 53-62. [CrossRef] [PubMed]

59. Reis, S.; Beys-da-Silva, W.; Tirloni, L.; Santi, L.; Seixas, A.; Termignoni, C.; Silva, M.; Macedo, A. The extremophile Anoxybacillus sp. PC2 isolated from Brazilian semiarid region (Caatinga) produces a thermostable keratinase. J. Basic Microbiol. 2020, 60, 809-815. [CrossRef]

60. Preczeski, K.; Dalastra, C.; Czapela, F.; Kubeneck, S.; Scapini, T.; Camargo, A.; Zanivan, J.; Bonatto, C.; Stefanski, F.; Venturin, B.; et al. Fusarium oxysporum and Aspergillus sp. as Keratinase Producers Using Swine Hair From Agroindustrial Residues. Front. Bioeng. Biotechnol. 2020, 8, 71. [CrossRef] [PubMed]

61. Cavello, I.; Urbieta, M.; Cavalitto, S.; Donati, E. Bacillus cytotoxicus Isolated from a Pristine Natural Geothermal Area Reveals High Keratinolytic Activity. Microorganisms 2020, 8, 796. [CrossRef] [PubMed]

62. Sharma, I.; Kango, N. Production and characterization of keratinase by Ochrobactrum intermedium for feather keratin utilization. Int. J. Biol. Macromol. 2021, 166, 1046-1056. [CrossRef]

63. Peng, Z.; Mao, X.; Zhang, J.; Du, G.; Chen, J. Biotransformation of keratin waste to amino acids and active peptides based on cell-free catalysis. Biotechnol. Biofuels 2020, 13, 61. [CrossRef]

64. Forgács, G.; Alinezhad, S.; Mirabdollah, A.; Feuk-Lagerstedt, E.; Horváth, I. Biological treatment of chicken feather waste for improved biogas production. J. Environ. Sci. 2011, 23, 1747-1753. [CrossRef]

65. Chaturvedi, V.; Verma, P. Metabolism of Chicken Feathers and Concomitant Electricity Generation by Pseudomonas aeruginosa by Employing Microbial Fuel Cell (MFC). J. Waste Manag. 2014, 2014, 928618. [CrossRef]

66. Patinvoh, R.; Feuk-Lagerstedt, E.; Lundin, M.; Sárvári Horváth, I.; Taherzadeh, M. Biological Pretreatment of Chicken Feather and Biogas Production from Total Broth. Appl. Biochem. Biotechnol. 2016, 180, 1401-1415. [CrossRef]

67. Wawrzkiewicz, K.; Lobarzewski, J.; Wolski, T. Intracellular keratinase of Trichophyton gallinae. J. Med. Vet. Mycol. 1987, 25, 261-268. [CrossRef] [PubMed]

68. Riessen, S.; Antranikian, G. Isolation of Thermoanaerobacter keratinophilus sp. nov., a novel thermophilic, anaerobic bacterium with keratinolytic activity. Extremophiles 2001, 5, 399-408. [CrossRef]

69. Nam, G.; Lee, D.; Lee, H.; Lee, N.; Kim, B.; Choe, E.; Hwang, J.; Suhartono, M.; Pyun, Y. Native-feather degradation by Fervidobacterium islandicum AW-1, a newly isolated keratinase-producing thermophilic anaerobe. Arch. Microbiol. 2002, 178, 538-547. [CrossRef] [PubMed]

70. Bidzhieva, S.; Derbikova, K.; Kublanov, I.; Bonch-Osmolovskaya, E. Capacity of Hyperthermophilic Crenarchaeota for Decomposition of Refractory Proteins ( $\alpha$ - and $\beta$-keratins). Microbiology 2014, 83, 880-887. [CrossRef]

71. Dalmaso, G.; Lage, C.; Mazotto, A.; Dias, E.; Caldas, L.; Ferreira, D.; Vermelho, A. Extracellular peptidases from Deinococcus radiodurans. Extremophiles 2015, 19, 989-999. [CrossRef]

72. Manczinger, L.; Rozs, M.; Vágvölgyi, C.; Kevei, F. Isolation and characterization of a new keratinolytic Bacillus licheniformis strain. W. J. Microbiol. Biotechnol. 2003, 19, 35-39. [CrossRef]

73. Li, Q. Structure, Application, and Biochemistry of Microbial Keratinases. Front. Microbiol. 2021, 12, 1510. [CrossRef]

74. Kumar, R.; Balaji, S.; Uma, T.; Mandal, A.; Sehgal, P. Optimization of influential parameters for extracellular keratinase production by Bacillus subtilis (MTCC9102) in solid state fermentation using Horn meal-a biowaste management. Appl. Biochem. Biotechnol. 2010, 160, 30-39. [CrossRef]

75. Prakash, P.; Jayalakshmi, S.; Sreeramulu, K. Production of keratinase by free and immobilized cells of Bacillus halodurans strain PPKS-2: Partial characterization and its application in feather degradation and dehairing of the goat skin. Appl. Biochem. Biotechnol. 2010, 160, 1909-1920. [CrossRef]

76. El-Gendy, M. Keratinase production by endophytic Penicillium spp. Morsy1 under solid-state fermentation using rice straw. Appl. Biochem. Biotechnol. 2010, 162, 780-794. [CrossRef]

77. da Gioppo, N.; Moreira-Gasparin, F.; Costa, A.; Alexandrino, A.; de Souza, C.; Peralta, R. Influence of the carbon and nitrogen sources on keratinase production by Myrothecium verrucaria in submerged and solid-state cultures. J. Ind. Microbiol. Biotechnol. 2009, 36, 705-711. [CrossRef] [PubMed]

78. Costantini, M.; Ferrante, V.; Guarino, M.; Bacenetti, J. Environmental sustainability assessment of poultry productions through life cycle approaches: A critical review. Trends Food Sci. Technol. 2021, 110, 201-212. [CrossRef]

79. Bagewadi, Z.; Mulla, S.; Ninnekar, H. Response surface methodology based optimization of keratinase production from Trichoderma harzianum isolate HZN12 using chicken feather waste and its application in dehairing of hide. J. Environ. Chem. Eng. 2018, 6, 4828-4839. [CrossRef] 
80. de Oliveira, C.; de Souza, A.; de Castro, R. Bioconversion of chicken feather meal by Aspergillus niger: Simultaneous enzymes production using a cost-effective feedstock under solid state fermentation. Indian J. Microbiol. 2019, 59, 209-216. [CrossRef] [PubMed]

81. de Souza, P.; Bittencourt, M.; Caprara, C.; de Freitas, M.; de Almeida, R.; Silveira, D.; Fonseca, Y.; Ferreira Filho, E.; Pessoa Junior A.; Magalhães, P. A biotechnology perspective of fungal proteases. Braz. J. Microbiol. 2015, 46, 337-346. [CrossRef]

82. Gong, J.; Ye, J.; Tao, L.; Su, C.; Qin, J.; Zhang, Y.; Li, H.; Li, H.; Xu, Z.; Shi, J. Efficient keratinase expression via promoter engineering strategies for degradation of feather wastes. Enzyme Microb. Technol. 2020, 137, 109550. [CrossRef] [PubMed]

83. Zhang, R.; Gong, J.; Su, C.; Qin, J.; Li, H.; Li, H.; Shi, J.; Xu, Z. Recombinant expression and molecular engineering of the keratinase from Brevibacillus parabrevis for dehairing performance. J. Biotechnol. 2020, 320, 57-65. [CrossRef] [PubMed]

84. Xiao, J.; Peng, B.; Su, Z.; Liu, A.; Hu, Y.; Nomura, C.; Chen, S.; Wang, Q. Facilitating Protein Expression with Portable 5'-UTR Secondary Structures in Bacillus licheniformis. ACS Synth. Biol. 2020, 9, 1051-1058. [CrossRef] [PubMed]

85. Ben Elhoul, M.; Zaraî Jaouadi, N.; Bouacem, K.; Allala, F.; Rekik, H.; Mechri, S.; Khemir Ezzine, H.; Miled, N.; Jaouadi, B. Heterologous expression and purification of keratinase from Actinomadura viridilutea DZ50: Feather biodegradation and animal hide dehairing bioprocesses. Environ. Sci. Pollut. Res. Int. 2021, 28, 9921-9934. [CrossRef]

86. Cavello, I.; Chesini, M.; Hours, R.; Cavalitto, S. Study of the production of alkaline keratinases in submerged cultures as an alternative for solid waste treatment generated in leather technology. J. Microbiol. Biotechnol. 2013, 23, 1004-1014. [CrossRef] [PubMed]

87. Kumar, A. Aspergillus nidulans: A Potential Resource of the Production of the Native and Heterologous Enzymes for Industrial Applications. Int. J. Microbiol. 2020, 2020, 8894215. [CrossRef] 